\title{
Analysis of Influence of China Commercial Bank Credit Behavior on Monetary Policy Effect
}

\author{
Zhao Yanni* \\ Yunnan University Dianchi College \\ Kunming, China \\ 324040828@qq.com \\ * Corresponding Author
}

\author{
Feng Zhiyong \\ School of economics, Yunnan University \\ Kunming, China \\ 99627085@qq.com
}

\begin{abstract}
Regulation of monetary policy may not achieve desired effect. Consistency between commercial bank credit behavior and monetary policy orientation can greatly affect the effectiveness of monetary policy from the perspective of China. In the paper, possible influence of several commercial bank credit behaviors on monetary policy is analyzed. Several countermeasures are proposed.
\end{abstract}

Keywords-monetary policy; commercial bank; credit behavior

\section{INTRODUCTION}

Fluctuation range of economic conditions in various countries increased compared with previous conditions with strengthening of economic ties among various countries all over the world as well as innovation of various financial products and financial behaviors. It is more and more important to maintain continuous and healthy economy development through monetary policy. However, each monetary policy regulation may not be necessarily to achieve the desired effect historically. There are many factors influencing monetary policy, such as time lag effect, anticipated effect, etc. Since China economic activities are based on indirect financing, commercial bank occupies an important position in the market. However, loan lending is the most important business in capital operation of commercial bank. Therefore, influence of commercial bank credit behavior on monetary policy is mainly considered.

\section{INFLUENCE OF COMMERCIAL BANK CREDIT BEHAVIOR ON MONETARY POLICY}

\section{A. Influence of commercial bank over-lending behavior on monetary policy}

The concept of over-lending can be comprehended as follows: actual loan lending quantity of commercial bank is higher than the loan lending quantity under the condition for realizing maximum profits. Over-lending phenomenon is particularly prominent during the period of implementing loan scale restriction in China. "Overlending" is a "normal state" of China commercial bank behavior during the period from 1985 to 1997 . It can be said that policy behavior of central bank to control loan scale of commercial bank during the period did not achieve desired effect. Currently, China has canceled the restriction on commercial bank loan scale, but over-lending phenomena still occur frequently, especially in high economic growth period.

The reason of commercial bank over-lending behavior can be explained from two operation stages of commercial bank. Firstly, before commercial bank asset allocation size reaches the principle of equality between its marginal revenue and marginal cost, commercial bank over-lending behaviors are mostly behaviors adopted from the perspective of pursuing profit maximization. Commercial banks will be more deviated to lend more loans in asset allocation aspect in order to improve own profit level. Secondly, when the marginal revenue levelis equivalent to marginal cost due to commercial bank external loan, commercial banks are willing to cooperate with tight monetary policy and contract loan lending scale. However, loan demand of all enterprises based on state-owned enterprises in the market is not reduced. Their capital demand level can form a reversed transmission mechanism on loan lending of commercial banks, thereby commercial bank can implement further credit expansion and loan lending beyond their own development demand, and overlending phenomena are rare in the stage of rapid economic growth.

Loan fund quantity obtained by the enterprise can not be prominently decreased under tight monetary policy during the period. Enthusiasm of investment in real economy field does not embody tight nature of monetary policy. Marketable capital scale growth speed is faster in the market, effect of tight monetary policy is weaker. Central bank may have to further intensify policy effort in order to achieve the desired effect of monetary policy for achieving anticipated objective under the condition. However, loans of commercial banks can be further concentrated to large-scale enterprises under such circumstance, and loan lending scale on small enterprises can be reduced, and distorted asset allocation behaviors for responding monetary policy and pursuing self-interest maximization can be realized. Such behaviors can lead to the result that large enterprises in economic field or mainstream economic field still obtain rapid increase, while small and medium-sized enterprises survive difficultly. As a result, monetary policy transmission process will be blocked by over-lending behavior of commercial banks, and monetary policy effect will be weakened. 


\section{B. Influence of commercial bank loan-cherishing behavior on monetary policy}

Loan-cherishing refers to a management behavior that commercial banks are still not willing to provide loans under the condition that they have lending capacity and lending object, and the borrowers are in line with conditions to apply for loans. Commercial banks worry about the risk of incapable repayment on lending. Banks are not willing to provide loans due to low risk control ability. The asset allocation is more deviated to deposit reserve and increase of held marketable securities.

Aiming at the reason of loan-cherishing, analyze as follows.. Firstly, current non-performing asset ratio and total bad asset rising of commercial banks aggravate management risk in the banking industry. Many commercial banks begin to rethink own loan orientation and loan lending business. China banking industry operation report in 2014 shows that non-performing loan ratio of China commercial banks in recent years are shown as following figure:[1]

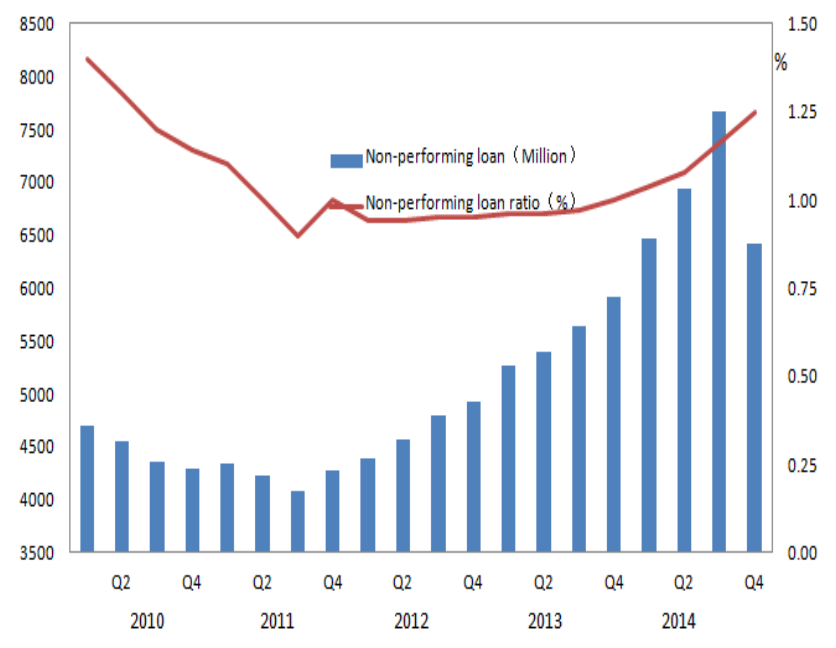

Figure 1. Non-performing loan of China commercial banks

Non-performing asset ratio and total non-performing assets are increased. However, loan demand and repayment condition, namely new loan pick-up rate and repayment rate of lent loans, are decisive factors affecting the credit behavior of commercial banks. Therefore, it is easy to understand loan-cherishing behavior of commercial banks.

Secondly, interest rate liberalization is constantly promoted. In addition, bank deposit loss pressure increased due to monetary fund deposit alternative products with convenient use, such as Yu'ebao, etc. Deposit increase rate showed decline to certain degree as shown in the following figure.

Commercial banks do not only need to change traditional profit model relying on asset expansion, but also should be more careful for lending behavior to enterprise under the background.

Finally, Basel agreement III is gradually applied to financial supervision system, new capital supervision standards are steadily pushed forward and implemented, therefore commercial bank management has suffered from great pressure. Corporate governance structure of China commercial banks has not been effectively and scientifically established. Strict financial regulation system unilaterally strengthens risk constraint mechanism in the economic transition process. Although it can play certain role to guard against financial risks, too cautious credit review is inevitably caused as a result.

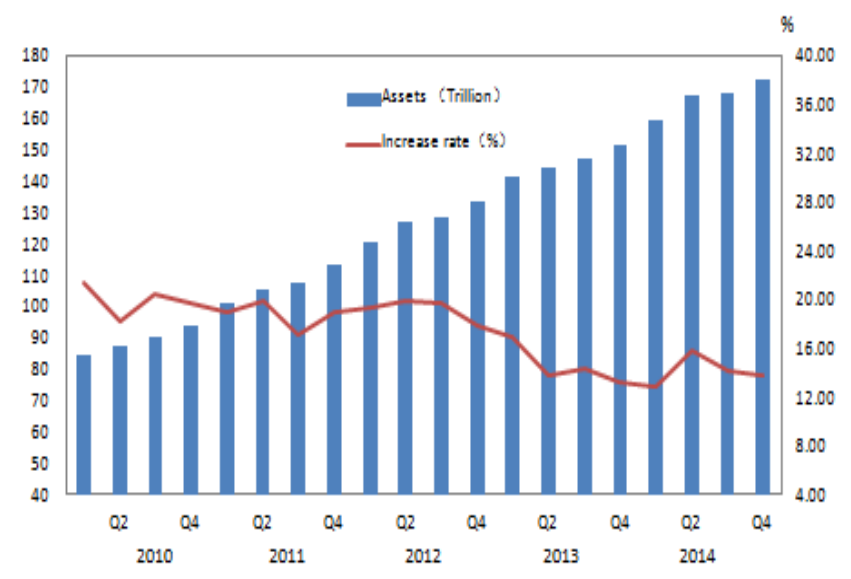

Figure 2. Assets of commercial bank

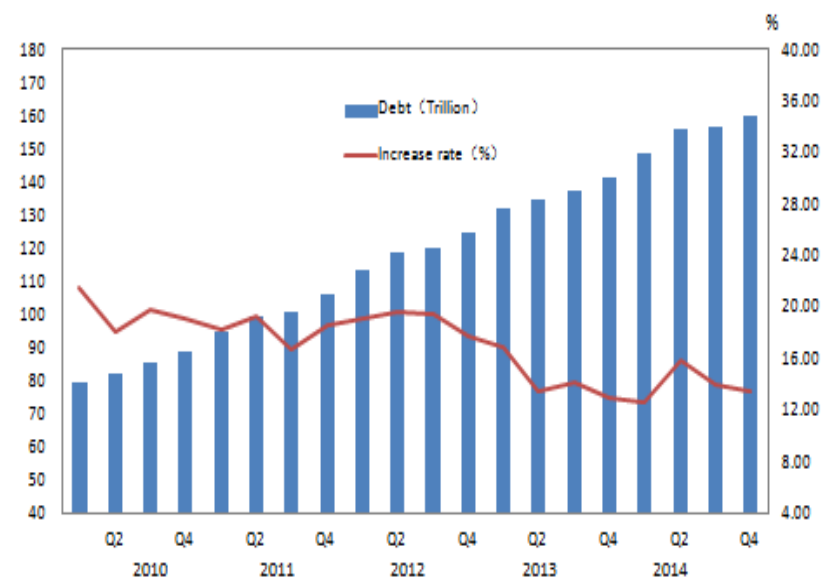

Figure 3. Debt of commercial bank

China commercial banks generally adopt head office and branch system. Monetary transmission link is artificially extended under transmission at various levels such as head office, provincial bank, municipal bank and county bank. Behavior deposition consequence of the credit decision-making is further intensified. Commercial banks do not randomly expand credit for loan lending any longer. Though statutory reserve ratio of commercial bank is lowered by the central bank's expansionary monetary policy, available cash of commercial banks increased, banks will be more deviated to increase of excess deposit reserve and held marketable securities during adjustment of assets allocation. A large number of "lost money" is produced by the measure, namely the increased money supply cannot correspondingly enter the real economy field according to intension of monetary policy, which is penetrated into non-entity economy field [2], namely the commercial banks create a so-called "black hole" to absorb potentially increased money supply due to expansionary monetary policy of the people's bank as a result, thereby blocking monetary policy transmission process, and greatly reducing the effect of monetary policy. 


\section{Influence of commercial bank loan concentration behavior on monetary policy}

Commercial bank loan concentration refers that commercial bank loans are concentrated to one industry or one region or one client. Credit concentration risk can be produced if one bank suffers from loan concentration.

Loan concentration phenomenon is always very significant in China commercial bank. The loan business of commercial bank has been always inclined to manufacturing enterprises in China. Data at the end of each fiscal year from 2008 to 2012 show that loans of all commercial banks have moderate concentration, and loan balance of manufacturing industry ranks No. 1 in all banks. Loans in manufacturing industry show slow increase trend since 2009. Loans in the manufacturing industry accounted for more than $20 \%$ at the end of 2012 . Average proportion of manufacturing industry loan in enterprise loan was $26.58 \%$ for major listed commercial banks. Huaxia Bank had the highest proportion of $32.71 \%$, and Industrial and Commercial Bank of China had the lowest proportion of $21.36 \%$. Industry concentration of commercial bank loans is strengthened [3]. However, data in the past two years shows that company loan balance of commercial banks was 50.77 trillion Yuan in 2014 from the perspective of loan orientation according to 2014 China banking industry operation report, which was increased by $12.3 \%$ compared with 45.21 trillion Yuan in 2013, wherein a lot of loans were lent to manufacturing industry. Main industry orientation of commercial bank loans in 2014 shows that manufacturing industry loan balance accounted for nearly $20 \%$, which was slightly reduced compared with that in 2013. However, the proportion was still large, and it is obvious that there is still phenomenon of loan concentration in China at present.

Commercial bank loan concentration behavior has continuity feature, especially for some large enterprises or individuals with frequent business contact with the bank. Since some industries are rapidly developed at the beginning, banks are selected to lend loans to enterprises and companies in the industry under more relaxed conditions with economic situation, bank and enterprises produce closer relationship in the industry, especially some companies with larger scale in the industry. When the industry development is declined to certain extent, banks still prefer to lend loans to large companies with previous business contact compared with some small enterprises with better development prospect. Loan concentration phenomena can not be corrected to certain extent due to the continuity.

The above analysis shows that when central bank decides to implement tight monetary policy, though strict tight monetary policy will lead to shrinkage of bank credit business, banks still can select to implement loose loan conditions aiming at some enterprises with high money demand, good development prospect and more frequent business contact. Credit scale of such enterprises will be enlarged. While the bank will shrink credit scale for other enterprises. Such behaviors of concentrating loan business to a part of enterprises can realize maximization of bank own profits under the constraint conditions of tight monetary policy. The behavior also can leads to inflation for enterprises obtaining loans in the market, namely a local inflation result characterized by asset price rising.
Therefore, monetary policy effect is diluted. It also can be discovered under the background of loose monetary policy. Though most enterprises can obtain loans under loose monetary policy, loan balance of popular industries account for extremely high proportion, which is not beneficial for fair competition in the whole market, and transmission process of monetary policy to the whole real economy is hindered, thereby leading to unbalanced development to all departments in the economic system, which is also not beneficial for healthy development of economy in one country, and violates original intention of monetary policy.

\section{COUNTERMEASURES FOR BEHAVIORS THAT COMMERCIAL BANK CREDIT BEHAVIOR AFFECTS MONETARY POLICY EFFECTIVENESS}

As the content in the previous text, commercial banks can determine fund resource allocation efficiency under each monetary policy adjustment in China to large extent. Commercial banks should play its role in the following aspects: whether fund under loose monetary policy can be timely lent to enterprise with loan demand, whether credit can be sufficiently expanded for stimulating investment increase, whether commercial banks can realize intension of monetary policy through timely shrinking credit scale and other business operation under tight monetary policy. Loan-cherishing behavior of commercial banks has especially important significant for realizing monetary policy, which can even affect long-term development of economy in one country. However, differentiation and inconsistence of commercial bank loan-cherishing behavior and central bank policy can be caused due to different goals. In the battle between commercial bank and central bank, after central bank operates policy for the first step according to economic condition, commercial banks always can implement corresponding asset allocation selection for realizing own profit maximization according to monetary policy formulated by central bank and under various constraint conditions such as financial regulatory framework, etc. Therefore, the following measures can be adopted for commercial banks in order to change the situation:

Firstly, credit release quantity of state-owned commercial banks based on four major banks accounts for high proportion in total national credit in China currently. Interest rate marketization is constantly promoted at present, further deepen joint-stock system reform of stateowned large banks, dredge transmission channels of monetary policy in the large banks should be considered, and strengthen the monetary policy conduction effect in the large banks aiming at the above actual condition, thereby enhancing the effect of monetary policy, vigorously developing private banks, and optimizing market structure. Overall development in the system can be driven by forces outside the system of private banks and private capital. Increment should be better utilized, and stock revitalization can be driven by increment optimized allocation. Overall efficiency of the banking industry can be improved due to competitiveness enhancement of the whole market finally. Therefore, the response ability of commercial banks aiming at monetary policy signals also can be accelerated, thereby improving transmission effect of monetary policy. 
Secondly, strict financial supervision framework makes commercial banks more cautious in lending. Certain shrinkage effect can be produced on bank credit, it can further produce unbeneficial influence on economic growth under current situation that economy downward pressure is increased, and monetary easing signal is stronger and stronger. Therefore, financial regulators should consider further optimizing management mechanism on China capital adequacy ratio. Different financial regulation plans can be selected for banks in different scales and different categories, differentiated regulation index can be implemented, thereby improving effectiveness and rationality of supervising commercial banks in China. Such differentiated management plan can also assist commercial bank to allocate asset according to own situation, thereby maximizing effectiveness of monetary policy.

Thirdly, China commercial bank should further promote comprehensive management actually, and optimize the structure of its profit source. Currently, rate difference income still accounts for quite high proportion in the profit source of banking industry in China. It is obvious that China commercial bank is still inclined to traditional business and profit modes. Such traditional mode cannot be maintained for long term under the trend that financial disintermediation is constantly aggravated. Commercial banks must actively develop business and cultivate new profit sources in order to keep stable growth of profits. Commercial bank behavior adjustment and configuration degree of monetary policy can be enhanced. Commercial banks can keep its profit level constant through other fields under the condition of complying with currency policy direction, thereby avoiding offset to monetary policy effect due to some behavior adjustments contrary to monetary policy direction.

\section{REFERENCES}

[1] Zhang Qiang. Li Yuanhang, Liao Yibin. "Influence of commercial bank behavior on monetary policy transmission effect," Financial Forum, 2011 , vol. 3 , pp. 15-18.

[2] Chen Xi. "Research on risk influence factor in bank holding company," Master Degree Theses of Northeast University of Finance and Economics, 2012.

[3] Pei Ping, Xiong Peng. "Research on China Monetary Policy Transmission," Beijing. China Financial Publishing House, 2009.

[4] Wang Yuerong. "Empirical Research on income and risk effect of listed commercial bank loan concentration in China," Master Degree Theses of Northeast University of Finance and Economics, 2013.

[5] He Yong. "Research on the Loan Fixed price in the Credit Business Manage of China's Commercial Bank," Economy and Management.2008, , vol. 22, pp. 61-68.

[6] Liu Liang. "Impact Analysis of Internet Financial Credit Reporting to China's Commercial Bank Credit Monopoly", South China Finance.2014, vol. 8, pp. 21-26.

[7] Wen Zhongping, Zhou Sheng, Shi Benshan. "Research on Internal Marketization Management of Credit Operation in Chinese Commercial Banks," Journal of Southwest Jiaotong University(Social Sciences), 2011, vol. 12 , pp. 74-77.

[8] Wang Zhibin,Mao Yanjun. "The Effect of Bank Capital Regulation on Credit Transmission Mechanism of Monetary Policy," Journal of Xi'an Jiaotong University(Social Sciences). 2013, vol. 33, pp. 31-35.

[9] Sun Yanhong, Zhang Hong. "Effectiveness analysis of monetary policy transmission by bank credit channels," Journal of University of Science and Technology of China, 2012, vol. 12, pp. 954-960. 